\title{
ENERGY CONSUMPTION DURING TRANSPORTATION ALONG THE PALM OIL SUPPLY CHAIN IN MALAYSIA
}

\author{
FAUZIAH ARSHAD*; VIJAYA SUBRAMANIAM*; BALU NAMBIAPPAN*; AZMAN ISMAIL* \\ and SUMIANI YUSOFF**
}

\begin{abstract}
The Life Cycle Inventory (LCI) analysis on the energy consumption was based on the study of the transportation of palm oil (PO), refined, bleached and deodourised (RBD) palm olein (POo) and palm stearin (POs) throughout the PO supply chain beginning from the transportation of the oil palm pollinated bunches from the 'mother palm' to the transportation of the RBD PO and its fractionated products, namely $R B D P O o$ and RBD POs from refineries/fractionation plants to the ports and finally to the retailers. The $L C I$ analysis found that based on the production of $1 t R B D P O$, the transportation of fresh fruit bunches (FFB) from plantations to mills consumed the highest energy followed by the transportation of POo from refineries to retailers and the transportation of crude palm oil (CPO) from PO mills to refineries, while the transportation of pollinated fruit bunches, germinated seeds and seedlings consumed the least amount of energy. The energy consumption on the basis of the production of $1 t R B D P O$ for the transportation of FFB from plantations to mills, RBD POo from refineries to retailers and CPO from mills to refineries were 197.12 MJ, 192.78 MJ and 151.50 MJ, respectively. Based on the actual production of the materials transported on an annual basis, it was estimated that the transportation of RBD PO, RBD POo and RBD POs along the palm oil supply chain consumed 7.025 billion MJ (0.168 Mtoe) energy per year.
\end{abstract}

\section{Keywords: Life Cycle Inventory, energy consumption, transportation, palm oil supply chain, palm oil, palm olein, palm stearin.}

Date received: 2 November 2018; Sent for revision: 21 November 2018; Received in final form: 24 January 2019; Accepted: 27 June 2019.

\section{INTRODUCTION}

The history of oil palm, Elaeis guineensis in Malaysia started as an ornamental plant in the late 1870s. However, the commercial planting of oil palm was only realised in 1917 when the Tenamaran Estate in Selangor was established (Nambiappan et al., 2018). Today, oil palm is the largest cultivated crop in the country with a total planted area of 5.85 million hectares (MPOB, 2019) and producing 19.52 million tonnes of crude palm oil (CPO) in 2018 (Kushairi et

\footnotetext{
Malaysian Palm Oil Board, 6 Persiaran Institusi, Bandar Baru Bangi, 43000 Kajang, Selangor, Malaysia. E-mail: fauziah@mpob.gov.my

** Institute of Ocean and Earth Sciences (IOES), C308, Institute of Advanced Building, Universiti Malaya, 50603 Kuala Lumpur, Malaysia.
}

al., 2019). Palm oil is the biggest edible oil traded among the 17 major oils and fats in the world market. The sector contributes significantly to the national agricultural Gross Domestic Product (GDP), generating RM 67.49 billion in export earnings in 2018 (DOSM, 2019) and is one of the pillars of Malaysia's economy. The many applications of palm oil and palm oil products in food as well as non-food products have been well established throughout the world mainly because of its versatility.

With the expansion in global economy, the various aspects in the production and consumption patterns have become international challenges in sustainable management (Giebler, 2013). Transportation is an important component in the palm oil supply chain. According to the Bureau of Transport and Communications Economics, Australia (BTCE, 
1995), transportation is one of the main sources of greenhouse gas (GHG) from the burning of fossil fuel. The transport sector is accountable to more than a quarter of the total carbon dioxide $\left(\mathrm{CO}_{2}\right)$ emission worldwide (Ghadimzadeh et al., 2015). The combustion processes from transport activities are the major contributors of $\mathrm{CO}_{2}$ and other gaseous pollutants such as nitrogen oxide $\left(\mathrm{N}_{2} \mathrm{O}\right)$ and carbon monoxide $(\mathrm{CO})$. The $\mathrm{CO}$ produced is primarily due to the incomplete combustion of vehicle fuel (Hirota, 2010). Global atmospheric concentration of GHG has increased significantly due to human activities since the eighteenth century when the Industrial Revolution started and is now far exceeding preindustrial values (IPCC, 2007). $\mathrm{CO}_{2}$ is by far the most important anthropogenic GHG. Increases in the global $\mathrm{CO}_{2}$ concentrations are mainly originating from fossil fuel use with land use change providing another significant but smaller contribution (IPCC, 2007). Continued GHG emissions warm the earth resulting in increasing the earth surface temperature. These emissions can have adverse impacts to both human and the environment. The impacts of climate change on the ecosystem include flooding and droughts, decrease in food production, destruction of marine life and the availability of fresh water is reduced (IPCC, 2007).

A huge portion of energy is used during transportation. Ong et al. (2011) in his review on the emissions generated by road transport in Malaysia indicated that the energy consumption from the transportation sector in Malaysia had been on an increasing trend. A study on the Life Cycle Inventory (LCI) on the energy consumption from fossil fuel used by the transportation sector in the Malaysian oil palm industry is therefore beneficial to the industry in order to gauge the level of energy used and the diesel consumption during transportation throughout the palm oil supply chain. The findings of this study can be a platform to improve on the sustainable transportation policies in order to reduce impact to the environment from the transportation sector by the Malaysian oil palm industry.

This article presents the energy consumption from the transportation along the palm oil supply chain beginning from transportation of pollinated fruit bunches from 'mother palm' for the production of the germinated seeds until the transportation of the refined, bleached and deodourised (RBD) palm oil (PO) and its fractionated products, i.e. RBD palm olein (POo) and palm stearin (POs) from refineries/fractionation plants to ports and retailers. This article also highlights an estimation of the total annual energy and diesel consumptions from the transportation process in the production of palm oil (PO), RBD POo and RBD POs along the palm oil supply chain by the Malaysian oil palm industry.

\section{METHODOLOGY}

LCI for transportation includes the energy requirements and emissions generated (US EPA, 1993). The study was conducted using the LCI analysis from the input (resources) and output (emissions) data compiled and evaluated within the system boundary as in Figure 1. The input data included the energy and raw materials while the output data was the combustion emissions from the transportation involved throughout this study.

\section{System Boundary}

The transportation along the palm oil supply chain within the system boundary (Figure 1) starting from the transportation of the oil palm pollinated bunches from 'mother palm' to the seed producers; this was then followed by the transportation of the germinated seeds to the nurseries; seedlings to oil palm plantations; fresh fruit bunches (FFB) to palm oil mills; CPO to refineries/fractionation plants and finally transportation of the RBD PO and its fractionated products namely RBD POo and RBD POs to ports and retailers. The transportation of products during operation is not included in the system boundary such as the transportation of the FFB during in-field collection at the plantation. Previous study by Halimah et al. (2010) and Tan et al. (2010) respectively have also shown that transportation during operation, i.e. during transportation of pesticides and fertilisers at the nursery and plantation and transportation of bleaching earth from refinery to landfills were minimal.

\section{Functional Unit}

The functional units for the products in this study were as follows: pollinated fruit bunches: kgkm; seed: seedkm; seedling: seedlingkm; FFB: tkm; CPO: tkm; RBD PO: tkm; RBD POo: tkm and RBD POs: $\mathrm{tkm}$. One $\mathrm{kgkm}$ is defined as the transport of $1 \mathrm{~km}$ of the pollinated fruit bunches over $1 \mathrm{~km}$ and $1 \mathrm{tkm}$ is defined as the transport of $1 \mathrm{t}$ of the palm product concerned over $1 \mathrm{~km}$ while one seedkm and 1 seedlingkm are defined as the transport of one unit of the seed and seedling over $1 \mathrm{~km}$, respectively (Spielmann et al., 2004). The functional units are an important element in the LCI analysis when comparing different systems so as to enable the comparisons made are based on a common basis (Goedkoop et al., 2007).

\section{Allocation of Co-products}

An allocation was also given to the co-products produced and they were calculated on weight basis. For example, at the mill, during the production 


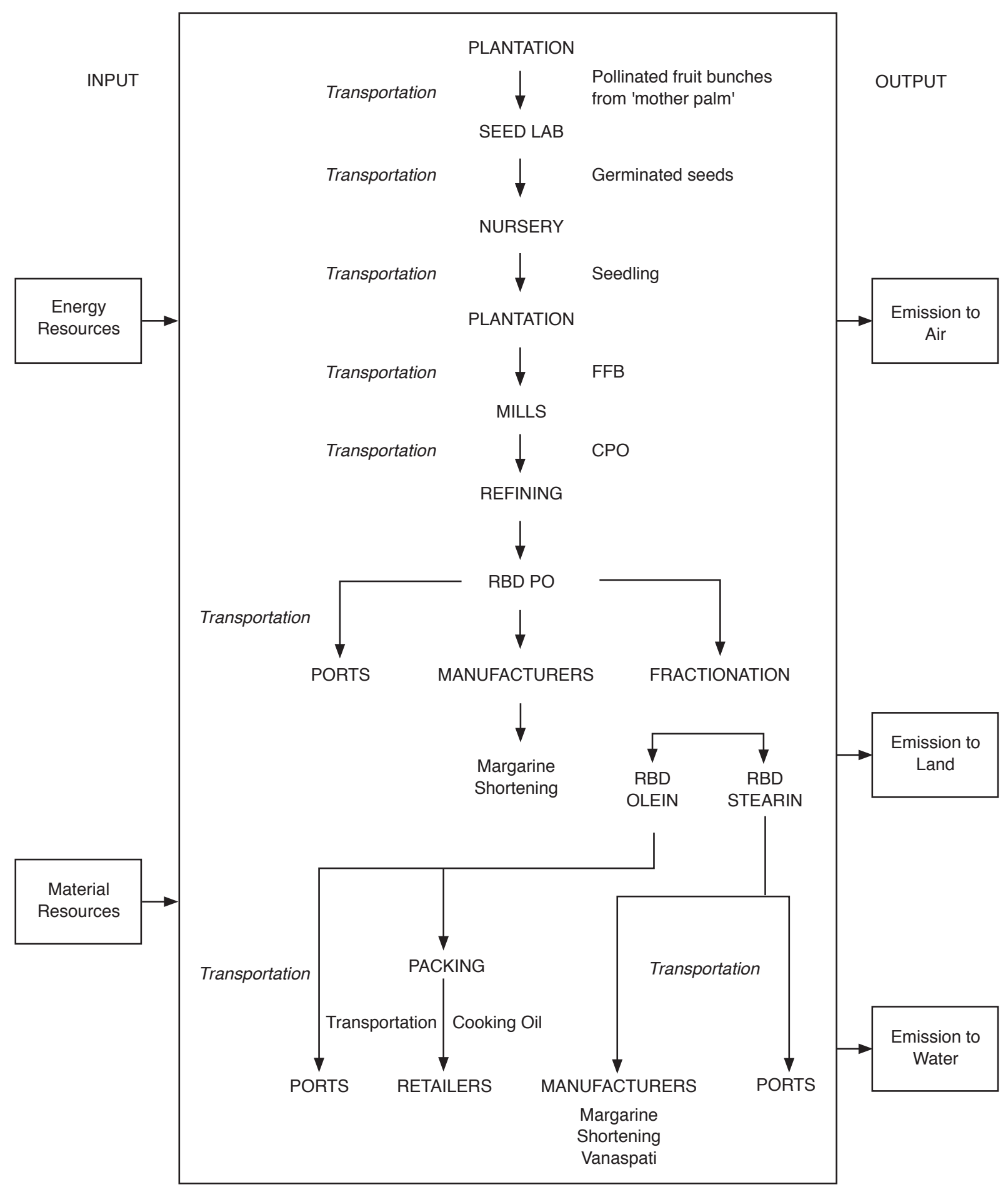

Note: PO - palm oil. RBD - refined, bleached and deodourised. CPO - crude palm oil. FFB - fresh fruit bunches. Source: Arshad et al. (2017).

Figure 1. System boundary for the transportation of palm oil, palm olein and palm stearin.

of $\mathrm{CPO}$, the palm kernel (PK) is an important coproduct. The allocation given is 71:29 (CPO:PK) (Choo et al., 2009). Palm fatty acid distillate (PFAD) is another co-product during the refining process of $\mathrm{CPO}$ at the refinery. The allocation given is 95.5:4.5 (RBD PO:PFAD). For the fractionation of the RBD PO, the allocation to produce RBD POo and RBD POs is 75:25 (RBD POo:RBD POs) (Tan et al., 2010).

\section{Data Collection and Sampling Design}

The inventory data on the energy input in this study were primary data which were obtained through questionnaires covering the oil palm seed producers, nurseries, oil palm plantations, palm oil mills and palm oil refineries in Malaysia. In order to ensure that the data were representative, sampling was done according to geographical coverage 
(covering Peninsular, Sabah and Sarawak); sizes of planted areas (covering estates: more than 1000 ha and smallholders: less than $40 \mathrm{ha}$ ); processing tonnage; different types of management and ownership (covering privately owned companies, government and state schemes); and covering the different transportation modes. In the determination of the average distance between each stage of the supply chain, the different locations, e.g. coastal and mainland was also considered in order to get good distribution coverage of the samples studied. To ensure the reliability of the data, the data gathered were verified through various communication channels, i.e. on-site interviews, e-mails, telephones and faxes.

Table 1 shows the values of the oil palm characteristics in the various stages of the palm oil supply chain used for the LCI analysis in the study.

\section{RESULTS AND DISCUSSION}

The energy consumption during the transportation process of each stage along the palm oil supply chain from the pollinated fruit bunches from 'mother palm' to the refined products based on the respective functional unit at each stage of the supply chain is shown in Table 2. These results were based on actual calculations from information gathered from the questionnaires on the type of fuel used, fuel consumption, amount of product transported, unladen weight of vehicles (empty weight), laden weight of vehicles (weight of vehicles with load) and transportation distance. The study involved eight nurseries, 113 plantations, 41 mills and nine refineries. The classification of vehicles similar to Switzerland was used in the study, i.e. vehicle classes $<3.5 \mathrm{t}$ (allocated gross vehicle weight range of $<3.5 \mathrm{t})$; vehicle $16 \mathrm{t}(3.5-20 \mathrm{t})$; vehicle $28 \mathrm{t}$ (>20$28 \mathrm{t}$ ) and vehicle $40 \mathrm{t}(>28-40 \mathrm{t})$ (Speilmann et al., 2004). This classification was selected instead of the classification of motor vehicles in Malaysia in view of the broad classification under Sections 5(1) (e) and (f) of the Road Transport Act 1987, i.e. motor vehicles carrying a load with the unladen weight (empty weight of vehicles) of more than $5 \mathrm{t}$ or less than 5 t respectively (KKR, 2007).

The values for the oil palm characteristics in Table 1 were used to determine the amount of materials of each product transported along the palm oil supply chain. For example, the amount of pollinated fruit bunch from 'mother palm' to produce one germinated seed was calculated based on the average number of seeds in a fruit bunch and the percentage of seed germination. The calculation is as follows: the average weight of one fruit bunch is equivalent to $20 \mathrm{~kg}$ with an average of 1500 fruits per bunch. These data were obtained from interviews during the study. Germination of seeds was taken as $85 \%$ to produce 1275 of germinated seeds. The amount of fruit bunch to produce one germinated seed is equivalent to $20000 \mathrm{~g} / 1275$ $=15.69 \mathrm{~g}$.

The percentage of culling (done at the nursery to remove poor quality seedlings) (Corley and Tinker, 2016) was used for the consideration on the amount needed to produce one seedling. The number of oil palms planted in 1 ha, the lifetime of the palms and the FFB yield were used to determine the amount of seedling to produce $1 \mathrm{t}$ of FFB. The calculations for these values are as follows: due to the culling process of 25\% (Corley and Tinker, 2016), 75 seedlings are produced from 100 germinated seeds. The amount of germinated seed to produce one

TABLE 1. THE OIL PALM CHARACTERISTICS USED IN THE STUDY

\begin{tabular}{lc}
\hline Average plantation area (ha) & 1495.82 \\
Average weight of fruit bunch $(\mathrm{kg})$ & 20 \\
Average No. of fruits in a bunch & 1500 \\
Germination of seeds $(\%)$ & 85 \\
Weight of germinated seeds with box $(2500$ seeds / box $)(\mathrm{kg})$ & 11 \\
Culling of seedlings $(\%)$ & 25 \\
Average weight of a 12-month old seedling $(\mathrm{kg})$ & 20 \\
FFB yield $(\mathrm{t}$ ha yr-1) & 21.51 \\
Palm per hectare & 142 \\
Palm lifetime $(\mathrm{yr})$ & 25 \\
FFB to produce $1 \mathrm{t}$ CPO $(\mathrm{t})$ & 3.61 \\
CPO to produce $1 \mathrm{t}$ RBD PO $(\mathrm{t})$ & 1.05 \\
RBD PO to produce $1 \mathrm{t}$ RBD POo $(\mathrm{t})$ & 1.29 \\
RBD PO to produce $1 \mathrm{t}$ RBD POs $(\mathrm{t})$ & 4.62 \\
\hline Note: FFB - fresh fruit bunches. & \\
CPO - crude palm oil. & \\
PO - palm oil. & \\
RBD - refined, bleached and deodourised. & \\
$\quad$ POo - palm olein. & \\
POs - palm stearin. &
\end{tabular}


TABLE 2. CONSUMPTION OF ENERGY FOR THE TRANSPORTATION OF THE POLLINATED FRUIT BUNCHES FROM 'MOTHER PALM', GERMINATED SEEDS, SEEDLINGS, CRUDE PALM OIL AND RBD PALM OIL, RBD PALM OLEIN AND RBD PALM STEARIN BASED ON THE RESPECTIVE FUNCTIONAL UNIT FOR EACH STAGE OF THE SUPPLY CHAIN

\begin{tabular}{|c|c|c|c|c|c|}
\hline $\begin{array}{l}\text { Product } \\
\text { transported }\end{array}$ & $\begin{array}{c}\text { Transport } \\
\text { route }\end{array}$ & $\begin{array}{c}\text { Average } \\
\text { distance } \\
(\mathbf{k m})\end{array}$ & $\begin{array}{c}\text { Amount } \\
\text { material } \\
\text { used }\end{array}$ & $\begin{array}{c}\text { Functional } \\
\text { unit }\end{array}$ & $\begin{array}{c}\text { Energy } \\
\text { consumption }\end{array}$ \\
\hline \multicolumn{6}{|c|}{ Nursery } \\
\hline $\begin{array}{l}\text { Pollinated fruit } \\
\text { bunches from } \\
\text { 'mother palm' }\end{array}$ & $\begin{array}{l}\text { Plantation to } \\
\text { seed producer }\end{array}$ & 51 & $15.69 \mathrm{~g}$ & $\begin{array}{l}1 \text { unit of germinated } \\
\text { seed }\end{array}$ & $\begin{array}{c}4.85 \times 10^{-4} \text { litres } \\
(0.017 \mathrm{MJ})\end{array}$ \\
\hline $\begin{array}{l}\text { Germinated } \\
\text { seeds }\end{array}$ & $\begin{array}{l}\text { Seed producer } \\
\text { to nursery }\end{array}$ & 86 & 1.33 seeds & 1 unit of seedling & $\begin{array}{c}6.36 \times 10^{-4} \text { litres } \\
(0.023 \mathrm{MJ})\end{array}$ \\
\hline Seedlings & $\begin{array}{l}\text { Nursery to } \\
\text { plantation }\end{array}$ & 70 & 0.26 seedling & $1 \mathrm{t}$ of FFB & $\begin{array}{c}2.76 \times 10^{-4} \text { litres } \\
\left(9.89 \times 10^{-3} \mathrm{MJ}\right)\end{array}$ \\
\hline \multicolumn{6}{|c|}{ Plantation } \\
\hline $\begin{array}{l}\text { Fresh fruit } \\
\text { bunches }\end{array}$ & $\begin{array}{l}\text { Plantation } \\
\text { to mill }\end{array}$ & 31 & $3.61 \mathrm{t}$ & $1 \mathrm{t}$ of $\mathrm{CPO}$ & $\begin{array}{l}5.23 \text { litres } \\
(187.76 \mathrm{MJ})\end{array}$ \\
\hline \multicolumn{6}{|c|}{ Palm oil mill } \\
\hline Crude palm oil & Mill to refinery & 164 & $1.05 \mathrm{t}$ & $1 \mathrm{t}$ of RBD PO & $\begin{array}{l}4.22 \text { litres } \\
\text { (151.50 MJ) }\end{array}$ \\
\hline \multicolumn{6}{|c|}{ Palm oil refinery } \\
\hline \multicolumn{6}{|c|}{ Refined oils for export } \\
\hline RBD palm oil & $\begin{array}{l}\text { Refinery } \\
\text { to ports }\end{array}$ & 67 & $1 \mathrm{t}$ & $1 \mathrm{t}$ of RBD PO & $\begin{array}{c}\text { Electricity: } \\
0.45 \text { kWhr }(1.62 \mathrm{MJ}) \\
\text { Diesel: } \\
0.32 \text { litres }(11.49 \mathrm{MJ}) \\
\text { Total }(13.11 \mathrm{MJ})\end{array}$ \\
\hline RBD palm olein & $\begin{array}{l}\text { Refinery } \\
\text { to ports }\end{array}$ & 21 & $1 \mathrm{t}$ & $1 \mathrm{t}$ of RBD PO & $\begin{array}{c}\text { Electricity: } \\
0.47 \text { kWhr }(1.69 \mathrm{MJ}) \\
\text { Diesel: } \\
\text { 0.84 litres }(30.16 \mathrm{MJ}) \\
\text { Total }(31.85 \mathrm{MJ})\end{array}$ \\
\hline RBD palm stearin & $\begin{array}{l}\text { Refinery } \\
\text { to ports }\end{array}$ & 18 & $1 \mathrm{t}$ & $1 \mathrm{t}$ of RBD PO & $\begin{array}{c}\text { Electricity: } \\
0.46 \text { kWhr }(1.66 \mathrm{MJ}) \\
\text { Diesel: } \\
0.59 \text { litres }(21.18 \mathrm{MJ}) \\
\text { Total }(22.84 \mathrm{MJ})\end{array}$ \\
\hline \multicolumn{6}{|c|}{ Refined oils for retailers } \\
\hline RBD palm oil & $\begin{array}{l}\text { Refinery } \\
\text { to retailers }\end{array}$ & 44 & $1 \mathrm{t}$ & $1 \mathrm{t}$ of $\mathrm{RBD} P O$ & $\begin{array}{l}2.11 \text { litres } \\
(75.75 \mathrm{MJ})\end{array}$ \\
\hline RBD palm olein & $\begin{array}{l}\text { Refinery } \\
\text { to retailers }\end{array}$ & 53 & $1 \mathrm{t}$ & $1 \mathrm{t}$ of RBD PO & $\begin{array}{l}5.37 \text { litres } \\
(192.78 \mathrm{MJ})\end{array}$ \\
\hline RBD palm stearin & $\begin{array}{l}\text { Refinery } \\
\text { to retailers }\end{array}$ & 63 & $1 \mathrm{t}$ & $1 \mathrm{t}$ of RBD PO & $\begin{array}{l}2.56 \text { litres } \\
(91.90 \mathrm{MJ})\end{array}$ \\
\hline
\end{tabular}

Note: PO - palm oil. RBD - refined, bleached and deodourised.

$\mathrm{CPO}$ - crude palm oil.

FFB - fresh fruit bunches. 
seedling is equivalent to $100 / 75=1.33$ germinated seed. Empty fruit bunches (EFB) of $21.51 \mathrm{t}$ were produced/hectare/year (based on data from this study). Therefore, the amount of seedling needed to produce $1 \mathrm{t}$ of FFB is equivalent to (142 number of palms per hectare/21.51 t FFB per hectare per year) divided by 25 years of the palm life time $=0.26$ seedlings.

The allocations for the production of the co-products during production of CPO, RBD PO, RBD POo and RBD POs determined the amount of FFB and CPO respectively. The amount of FFB needed for the production of $1 \mathrm{t} C \mathrm{CPO}$ was lower at $3.61 \mathrm{t}$ (i.e. $5 \mathrm{t}$ of $\mathrm{FFB}$ is normally processed to produce $1 \mathrm{t} \mathrm{CPO}$ ) to take into account the allocation by weight of $\mathrm{PK}$, a co-product in $\mathrm{CPO}$ production (Choo et al., 2009), while $1.05 \mathrm{t}$ of CPO was consumed in the production of RBD PO to take into account of the production of PFAD which is a coproduct in CPO processing (Tan et al., 2010). In view that fractionation of RBD PO to produce RBD POo and RBD POs was at the refinery itself, the energy consumption for RBD POo and RBD POs was based on the production of $1 \mathrm{t}$ RBD PO as these products were transported from the same location and using similar vehicles as the RBD PO. It was observed during the study that while the energy consumption for the transportation of the products in the various stages along the palm oil supply chain was mostly contributed from the diesel use, the energy consumption during transportation of the RBD PO, RBD POo and RBD POs was also contributed from electricity use as some of the refined products were transported to ports using pipelines.

For the computation of the diesel consumption, a factor of 0.8 was used for the return trip to take into account the diesel used on the empty return journey. This factor was used based on the fuel consumption for empty and fully loaded vehicles in the Swiss transport study (Speilmann et al., 2004). The energy was calculated based on the conversion: 1 kiloWatt hour (kWhr) is equivalent to 3.6 mega joules (MJ) and 1 litre of diesel fuel is equivalent to $35.9 \mathrm{MJ}$ (Energy Measurements and Conversions, 2010).

In order to make a comparison on the energy consumption between transportation of the different stages of the palm oil supply chain in the study, the energy consumption was computed on the basis of the production of $1 \mathrm{t}$ of RBD PO. From Figure 2, it was found that the transportation of the FFB from plantations to mills consumed the highest energy at 197.12 MJ followed by transportation of POo from refineries to retailers at $192.78 \mathrm{MJ}$ and transportation of CPO from palm oil mills to refineries at 151.50 MJ. In comparison, the transportation at the nursery stage consumed the least energy on the basis of production of $1 \mathrm{t}$ RBD PO. The energy consumption for the transportation of the pollinated bunches from 'mother palm', the germinated seeds and the seedlings were 0.02 MJ, 0.02 MJ and 0.04 MJ, respectively.

The transportation of FFB consumed the highest energy despite the fact that the distance from plantations to mills are not that far as the mills are strategically located at the centre of the plantations (Sivasothy, 2000). This is because the harvested FFB have to be delivered to the mills for processing within $24 \mathrm{hr}$ to ensure the quality of the CPO. Free fatty acids (FFA) will set in when bunches are bruised which occur during harvesting and transporting. The faster the fruit is crushed, the less FFA is produced, the better the yield and

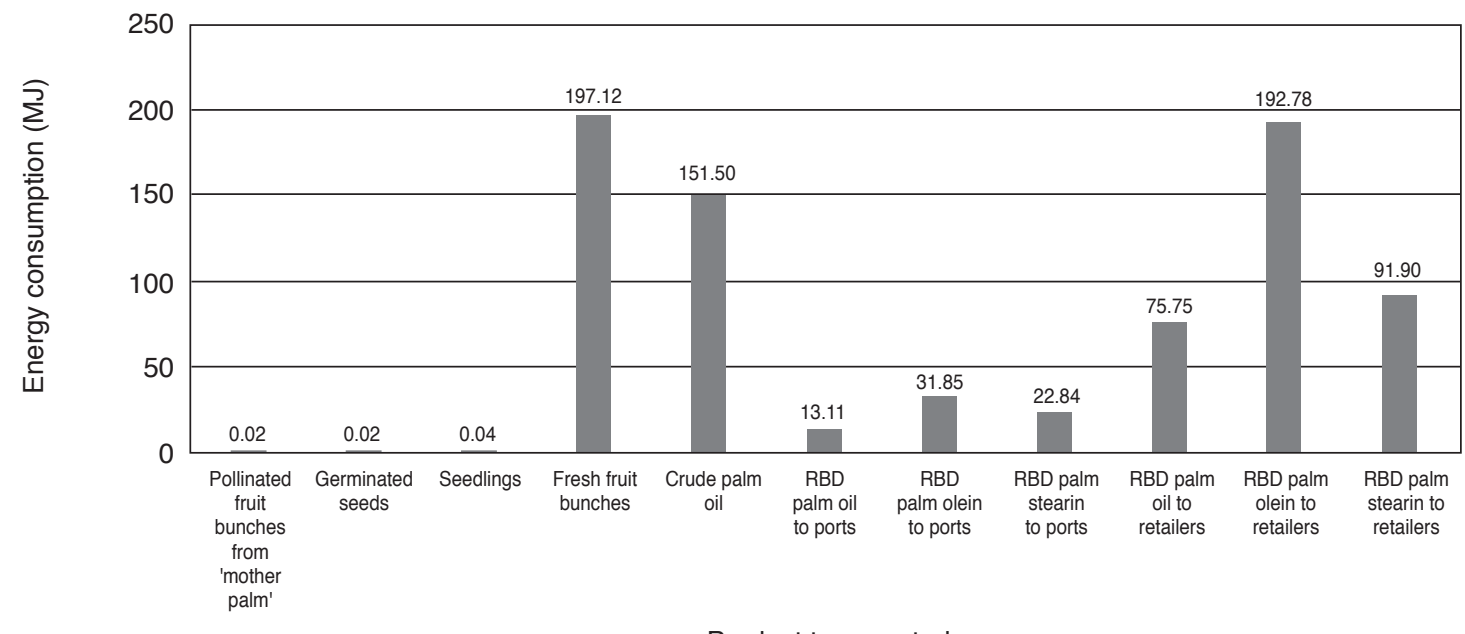

Product transported

Figure 2. Energy consumption for the transportation of the pollinated fruit bunches from 'mother palm', germinated seeds, seedlings, fresh fruit bunches, crude palm oil and refined, bleached and deodourised (RBD) palm oil (PO), RBD palm olein (POo) and RBD palm stearin (POs) based on the production of 1 t of $R B D P O$. 
quality of CPO. The main reason which contributed to the high value in the energy consumption was because the fruits are bulky leading to biomass being mostly transported instead of the oil. From the data in Table 1, it was shown that $3.61 \mathrm{t}$ of FFB was needed to produce each tonne of the CPO. The transport of RBD POo to retailers also contributed to high energy consumption because involvement of journeys within and sometimes across the states to re-packers as cooking oil and for further processing into other products. This led to higher amount of diesel consumption. The transportation of CPO from mills to refineries also consumed high amount of energy due to the longer average distance from the mills to refineries. The transport of the RBD PO, RBD POo and RBD POs to ports did not consume as much energy as most of the refineries are located close to the ports. The results of the GHG emissions (Arshad et al., 2017) also showed similar trend that transportation of the FFB and CPO from plantations to mills and from mills to refineries produced the highest GHG emissions based on the production of $1 \mathrm{t}$ RBD PO.

Table 3 presents the total energy consumption during the transportation process along the palm oil supply chain based on the production of materials in 2017 (MPOB, 2018). The RBD POo and RBD POs were calculated based on the difference between the total RBD POo and RBD POs produced and exported, respectively. In view that fractionation of the RBD PO to produce RBD POo and RBD POs (1.29 t of palm oil was needed to produce $1 \mathrm{t}$ of RBD POo and $4.62 \mathrm{t}$ of palm oil was needed to produce $1 \mathrm{t}$ of RBD POs) (Tan et al., 2009), the RBD PO for retail was determined based on the balance RBD PO after deduction to produce the RBD POo and RBD POs and RBD PO for export. Based on the actual production of materials along the palm oil supply chain, this study revealed that the total consumption of energy during the transportation from the pollinated fruit bunches from 'mother palm' up to the transportation of the RBD PO, RBD POo and RBD POs to ports for exports and to retailers for local consumption was 7.025 billion MJ or 0.168 Mtoe [1 mega joule (MJ) is equivalent to $2.388 \mathrm{E}-11$ million tonnes of oil equivalent (Mtoe)] (Unit Jugler, 2018). From Table 3, the diesel consumption during transportation along the palm oil supply chain was 195222208.83 litres yr $^{-1}$.

The determination of environmental interventions of vehicle operations, however, is not straightforward as it depends on numerous other factors including the type of engine and fuel used, load factor, age and the maintenance of the vehicle, kilometric performance, travel characteristics, i.e. speeds and accelerations, the geographical pattern and network condition, i.e. topography, road maintenance and density of transport as well as individual attitude of the drivers (André et al., 1999;
INFRAS, 2000). During the study, the brand and age of the vehicles used were varied. These differences affect the fuel efficiency and fuel consumption. Even though the questionnaires included request on this information, it was not possible as the people interviewed could not provide such information. The assumption is that the vehicles used the same amount of fuel based on the weight transported and distance travelled. This is the limitation of this study as the factors mentioned above influenced the fuel consumption.

\section{CONCLUSION AND RECOMMENDATIONS}

The findings of the LCI for the overall energy consumption for the different sectors of the palm oil supply chain on the basis of production of $1 \mathrm{t}$ RBD PO indicated that the transportation of FFB from plantations to mills consumed the highest energy followed by transportation of POo from refineries to retailers and transportation of $\mathrm{CPO}$ from palm oil mills to refineries. The transportation at the nursery stage, i.e. during transportation of the pollinated fruit bunches from 'mother palm', germinated seeds and seedlings consumed the least amount of energy.

Based on the total energy consumption from the actual production of materials on an annual basis for the transportation of RBD PO, RBD POo and RBD POs along the palm oil supply chain, the government and the Malaysian oil palm industry could aspire towards a more sustainable transportation in its strategic planning in the future to reduce the energy consumption from diesel use, which is nonrenewable. The use of railways to transport the $\mathrm{CPO}$ from palm oil mills to refineries and to transport the refined products to retailers could be considered for future development to reduce diesel use in view of the distance involved to transport CPO and refined palm oil products, particularly RBD POo. Spielmann et al. (2004) quoted by Arshad et al. (2017) that there could be savings from diesel consumption at 0.68 $\mathrm{g} \mathrm{t} \mathrm{km}^{-1}$ by using rail as opposed to $14.28 \mathrm{~g} \mathrm{t} \mathrm{km}^{-1}$ when transporting by road. This is because the train would be able to transport a much bigger load at any one time as compared to using the conventional mode by using lorry tankers. Transportation by rail can also be adopted during transportation of FFB from plantations to mills for those plantations that have flat terrains which are able to accommodate the railway system to reduce diesel consumption from road transport. This is also in line with the recommendations of the Intergovernmental Panel on Climate Change (IPCC) as one of the mitigating options to reduce GHG emissions is by increasing energy savings where in the transport sector, by modal shifts from road transport to using rail system (IPCC, 2007). 
TABLE 3. CONSUMPTION OF ENERGY FOR THE TRANSPORTATION OF THE POLLINATED FRUIT BUNCHES FROM 'MOTHER PALM', GERMINATED SEEDS, SEEDLINGS, CRUDE PALM OIL AND RBD PALM OIL, RBD PALM OLEIN AND RBD PALM STEARIN ON THE BASIS OF ACTUAL PRODUCTION IN 2017

\begin{tabular}{|c|c|c|c|c|c|c|}
\hline $\begin{array}{l}\text { Product } \\
\text { transported }\end{array}$ & From & $\begin{array}{l}\text { Average } \\
\text { distance } \\
(\mathbf{k m})\end{array}$ & $\begin{array}{l}\text { Based on the } \\
\text { production of }\end{array}$ & $\begin{array}{c}\text { Energy } \\
\text { consumption } \\
\text { based on } \\
\text { production of } \\
1 \text { unit or } 1 \mathrm{t} \\
\text { of materials }\end{array}$ & $\begin{array}{l}\text { Production } \\
\text { in } 2017^{*}\end{array}$ & $\begin{array}{c}\text { Energy } \\
\text { consumption } \\
\text { based on } \\
\text { production of } \\
\text { materials } \\
\text { in } 2017\end{array}$ \\
\hline \multicolumn{7}{|c|}{ Nursery } \\
\hline $\begin{array}{l}\text { Pollinated fruit } \\
\text { bunches from } \\
\text { 'mother palm' }\end{array}$ & $\begin{array}{l}\text { Plantation } \\
\text { to seed } \\
\text { producer }\end{array}$ & 51 & $\begin{array}{l}1 \text { unit of germinated } \\
\text { seed }\end{array}$ & $\begin{array}{c}4.85 \times 10^{-4} \\
\text { litres } \\
(0.017 \mathrm{MJ})\end{array}$ & $\begin{array}{c}138306881 \\
\text { germinated } \\
\text { seeds supplied }\end{array}$ & $\begin{array}{c}67078.84 \text { litres } \\
\text { (2 } 408130.26 \mathrm{MJ})\end{array}$ \\
\hline $\begin{array}{l}\text { Germinated } \\
\text { seeds }\end{array}$ & $\begin{array}{l}\text { Seed } \\
\text { producer } \\
\text { to nursery }\end{array}$ & 86 & 1 unit of seedling & $\begin{array}{l}6.36 \times 10^{-4} \\
\text { litres } \\
(0.023 \mathrm{MJ})\end{array}$ & $\begin{array}{l}87550026 \\
\text { seedlings } \\
\text { produced }\end{array}$ & $\begin{array}{l}55681.82 \text { litres } \\
\text { (998 977.21 MJ) }\end{array}$ \\
\hline Seedlings & $\begin{array}{l}\text { Nursery to } \\
\text { plantation }\end{array}$ & 70 & $1 \mathrm{t}$ of FFB & $\begin{array}{c}2.76 \times 10^{-4} \text { litres } \\
\left(9.89 \times 10^{-3} \mathrm{MJ}\right)\end{array}$ & $\begin{array}{l}101740900 \mathrm{t} \\
\text { of FFB } \\
\text { received by } \\
\text { mills }\end{array}$ & $\begin{array}{c}28080.49 \text { litres } \\
\text { (1 } 008089.53 \mathrm{MJ})\end{array}$ \\
\hline \multicolumn{7}{|c|}{ Plantation } \\
\hline $\begin{array}{c}\text { Fresh fruit } \\
\text { bunches }\end{array}$ & $\begin{array}{l}\text { Plantation } \\
\text { to mill }\end{array}$ & 31 & $1 \mathrm{t}$ of $\mathrm{CPO}$ & $\begin{array}{l}5.23 \text { litres } \\
(187.76 \mathrm{MJ})\end{array}$ & $\begin{array}{c}19919331 \mathrm{t} \\
\text { CPO produced }\end{array}$ & $\begin{array}{c}104178101.13 \text { litres } \\
\text { (3 } 739993830.56 \mathrm{MJ})\end{array}$ \\
\hline \multicolumn{7}{|c|}{ Palm oil mill } \\
\hline Crude palm oil & $\begin{array}{l}\text { Mill to } \\
\text { refinery }\end{array}$ & 164 & $1 \mathrm{t}$ of $\mathrm{RBD} \mathrm{PO}$ & $\begin{array}{l}4.22 \text { litres } \\
(151.50 \mathrm{MJ})\end{array}$ & $\begin{array}{c}14902376 t \\
\text { of RBD PO } \\
\text { produced }\end{array}$ & $\begin{array}{c}62888026.72 \text { litres } \\
(2257680159.24 \mathrm{MJ})\end{array}$ \\
\hline \multicolumn{7}{|c|}{ Palm oil refinery } \\
\hline \multicolumn{7}{|c|}{ Refined oils for export } \\
\hline RBD palm oil & $\begin{array}{l}\text { Refinery } \\
\text { to ports }\end{array}$ & 67 & $1 \mathrm{t}$ of RBD PO & $\begin{array}{c}\text { Electricity: } \\
0.45 \text { kWhr (1.62 MJ) } \\
\text { Diesel: } \\
0.32 \text { litres } \\
(11.49 \mathrm{MJ}) \\
\text { Total } \\
(13.11 \mathrm{MJ})\end{array}$ & $\begin{array}{c}1509993 \mathrm{t} \\
\text { of RBD PO } \\
\text { exported }\end{array}$ & $\begin{array}{c}\text { Electricity: } \\
2446 \text { 188.66 MJ } \\
\text { Diesel: } \\
483 \text { 197.76 litres } \\
\text { (17 } 346 \text { 799.58 MJ) } \\
\text { Total } \\
19792988.24 \mathrm{MJ}\end{array}$ \\
\hline RBD palm olein & $\begin{array}{l}\text { Refinery to } \\
\text { ports }\end{array}$ & 21 & $1 \mathrm{t}$ of RBD PO & $\begin{array}{c}\text { Electricity: } \\
0.47 \text { kWhr (1.69 MJ) } \\
\text { Diesel: } \\
0.84 \text { litres } \\
(30.16 \mathrm{MJ}) \\
\text { Total } \\
(31.85 \mathrm{MJ})\end{array}$ & 7700353 & $\begin{array}{c}\text { Electricity: } \\
13 \text { 013 596.57 MJ } \\
\text { Diesel: } \\
6468296.52 \text { litres } \\
\text { (232 } 211845.07 \mathrm{MJ}) \\
\text { Total } \\
245225441.64 \mathrm{MJ}\end{array}$ \\
\hline RBD palm stearin & $\begin{array}{l}\text { Refinery to } \\
\text { ports }\end{array}$ & 18 & $1 \mathrm{t}$ of RBD PO & $\begin{array}{c}\text { Electricity: } \\
0.46 \text { kWhr }(1.66 \mathrm{MJ}) \\
\text { Diesel: } \\
0.59 \text { litres } \\
(21.18 \mathrm{MJ}) \\
\text { Total } \\
(22.84 \mathrm{MJ})\end{array}$ & 1291979 & $\begin{array}{c}\text { Electricity: } \\
2 \text { 144 685.14 MJ } \\
\text { Diesel: } \\
762 \text { 267.61 litres } \\
\text { (27 } 365407.20 \mathrm{MJ}) \\
\text { Total } \\
\text { (29 510 092.34 MJ) }\end{array}$ \\
\hline \multicolumn{7}{|c|}{ Refined oils for retailers } \\
\hline RBD palm oil & $\begin{array}{l}\text { Refinery to } \\
\text { retailers }\end{array}$ & 44 & 1 t of RBD PO & $\begin{array}{l}2.11 \text { litres } \\
(75.75 \mathrm{MJ})\end{array}$ & 126996 & $\begin{array}{l}267961.56 \text { litres } \\
(9619820.00 \mathrm{MJ})\end{array}$ \\
\hline RBD palm olein & $\begin{array}{l}\text { Refinery to } \\
\text { retailers }\end{array}$ & 53 & $1 \mathrm{t}$ of RBD PO & $\begin{array}{l}5.37 \text { litres } \\
(192.78 \mathrm{MJ})\end{array}$ & 2975878 & $\begin{array}{l}15980464.86 \text { litres } \\
(573698688.47 \mathrm{MJ})\end{array}$ \\
\hline RBD palm stearin & $\begin{array}{l}\text { Refinery to } \\
\text { retailers }\end{array}$ & 63 & $1 \mathrm{t}$ of RBD PO & $\begin{array}{l}2.56 \text { litres } \\
(91.90 \mathrm{MJ})\end{array}$ & 1579317 & $\begin{array}{c}4043051.52 \text { litres } \\
\text { (145 145 549.57 MJ) }\end{array}$ \\
\hline Total & & & & & & $\begin{array}{c}195222208.83 \text { litres } \\
(7025081767.06 \mathrm{MJ})\end{array}$ \\
\hline
\end{tabular}

Note: PO - palm oil. RBD - refined, bleached and deodourised. $\mathrm{CPO}$ - crude palm oil.

FFB - fresh fruit bunches.

Source: *MPOB (2018). 


\section{ACKNOWLEDGEMENT}

The authors wish to thank the Director-General of MPOB for permission to publish this article.

\section{REFERENCES}

André, M; Hammarström, U and Reynaud, I (1999). Driving statistics for the assessment of pollutant emissions from road transportation. INRETS Report (3) LTE 9906. European Community DG VII.

Arshad, F; Tan, Y A and Yusoff, S (2017). A cradle-togate study of GHG emissions from the transportation of palm oil, palm olein and palm stearin using the Life Cycle Assessment approach. J. Oil Palm Res. Vol. 29(1): 120-129.

BTCE (1995). Greenhouse gas emissions from australian transport, long term projections. Report 88. Bureau of Transport and Communications Economics, Canberra, Australia.

Choo, Y M; Mohd Basri, W; Vijaya, S; Halimah, M and Zulkifli, H (2009). Life Cycle Assessment of palm oil. Paper presented at the $6^{\text {th }}$ International Planters Conference 2009. 22-24 June 2009, Kuala Lumpur.

Corley, R H V and Tinker, P B (2016). Seed germination and nurseries. The Oil Palm. Fifth edition. Wiley Blackwell, UK. p. 225-239.

DOSM (2019). Department of Statistics Malaysia, Putrajaya.

Energy Measurements and Conversions (2010). Energy Measurements and Conversions. http:// www.ecotec-systems.com/Resource/FUEL_ CONVERSION_WORK_SHEET.pdf, accessed in November 2010.

Geibler, J V (2013). Market-based governance for sustainability in value chains: Conditions for successful standard setting in the palm oil sector. J. Cleaner Production Vol. 56: 39-53.

Ghadimzadeh, A; Makmom, A A; Hosea, M K; Asgari, N; Shamsipour, R; Askari, A and Narany, T S (2015). Review of $\mathrm{CO}_{2}$ emissions from transportation in Malaysia. J. Environmental Science, Toxicology and Food Technology Vol. 9 (5): 61-70.

Goedkoop, M; Schryver, A D and Oele, M (2007). Defining goal and scope. SimaPro 7.1 Introduction to LCA with SIMAPRO. Pre Consultants, Amersfoort, Netherlands. p. 4-9.
Halimah, M; Zulkifli, H; Vijaya, S; Tan, Y A; Puah, C W; Chong, C L and Choo, Y M (2010). Life Cycle Assessment of oil palm seedling production (part 1). J. Oil Palm Res. Vol. 22(3): 878-886.

Hirota, K (2010). Comparative studies on vehicle related policies for air pollution reduction in ten Asian countries. Sustainability Vol. 2: 145-162.

IPCC (2007). $4^{\text {th }}$ Report of the Assessment of the IPCC on Climate Change. Intergovernmental Panel on Climate Change (IPCC), IPCC/OECD/IEA, Paris, France.

INFRAS (2000). Aktualisierung der Emissions- und Verkehrsgrundlagen. Infras Arbeitsunterlagen 15, Berlin.

KKR (2007). Road Transport Act 1987 (Act 333). Ministry of Works, Kuala Lumpur, Malaysia.

Kushairi, A; Ong-Abdullah, M; Nambiappan, N; Hishamuddin, E; Vijaya, S; Mohd Nor Izudin, Z B; Razmah, G; Sundram, S and Ahmad Parveez, G K (2018). Oil palm economic performance in Malaysia and R\&D progress in 2018. J. Oil Palm Res. Vol. 31(2): 165-194.

MPOB (2019). Malaysian Oil Palm Statistics 2018. $38^{\text {th }}$ Edition. MPOB, Bangi. 289 pp.

MPOB (2018). Production in 2017. Unpublished raw data.

Nambiappan, B; Azman, I; Norfadilah, H; Nazlin, I; Dayang Nazrima, S; Nik Abdullah, N I; Noraida, O; Kamalrudin, M S; Nur Ain, $\mathrm{M} \mathrm{H}$ and Kushairi, A (2018). Malaysia: 100 years of resilient palm oil economic performance. J. Oil Palm Res. Vol. 30(1): 13-25.

Ong, H C; Mahlia, T M I and Masjuki, H H (2011). A review on emissions and mitigation strategies for road transport in Malaysia. Renewable and Sustainable Energy Reviews Vol. 15: 3516-3522.

Sivasothy, K (2000). Palm oil milling technology. Advances in Oil Palm Research. Vol. 1. MPOB, Bangi. p. 744-782.

Spielmann, M; Kägi, T; Stadler, $\mathrm{P}$ and Tietje, $\mathrm{O}$ (2004). Life Cycle Inventories of transport services. Data v1.1 Ecoinvent Report No. 14. Swiss Centre for Life Cycle Inventories, Dübendorf.

Tan, Y A; Chow, M C; Halimah, M; Zulkifli, H; Vijaya S; Puah, C W; Nor Faizah, P; Neo, Y P; Haryantie, N; Chong, C W; Ma, A N; Choo, Y M and Mohd Basri, W (2009). Life Cycle Assessment (LCA) for food: Refined palm oil and its fractions. Paper presented at the 2009 International Conference on Oil Palm 
and the Environment. 14-15 August 2009, Malaysian Agro Exposition Park, Serdang.

Tan, Y A; Halimah, M; Zulkifli, H; Vijaya, S; Puah, C W; Chong, C L; Ma, A N and Choo, Y M (2010). Life Cycle Assessment of refined palm oil production and fractionation (part 4). J. Oil Palm Res. Vol. 22(3): 913-926.
Unit Jugler (2018). Convert everything with ease. https: / / www.unitjuggler.com/ convert-energyfrom-ktoe-to-MJ.html, accessed on 12 September 2018.

US EPA (1993). Life Cycle Assessment: Inventory Guidelines and Principles. US Environmental Protection Agency. 